\title{
Superior Vena Cava Stent Placement
}

National Cancer Institute

\section{Source}

National Cancer Institute. Superior Vena Cava Stent Placement. NCI Thesaurus. Code C137936.

Placement of a stent in the superior vena cava. 